DOI: https://doi.org/10.24127/ajpm.v8i3.2385

\title{
EKSPLORASI ETNOMATEMATIKA ISLAMI PADA TRADISI MAKAN BESAPRAH
}

\author{
Muhamad Firdaus ${ }^{1}$, Hodiyanto ${ }^{2}$ \\ ${ }^{1,2}$ Pendidikan Matematika, IKIP PGRI Pontianak \\ E-mail: $\quad$ kiranafirdiani@gmail.com ${ }^{l)}$ \\ hodiyanto@ikippgriptk.ac.id ${ }^{2)}$
}

Received 12 October 2019; Received in revised form 5 December 2019; Accepted 29 December 2019

\begin{abstract}
Abstrak
Tujuan dalam penelitian adalah untuk mendiskripsikan alat-alat yang digunakan maupun aktivitas yang dilakukan dalam tradisi makan besaprah pada upacara pernikahan melayu di Kecamatan Sambas. Metode yang digunakan dalam penelitian ini adalah penelitian kualitatif berupa etnografi. Teknik pengumpulan data yang digunakan adalah observasi, wawancara, dan dokumentasi sehingga alat pengumpul data yang digunakan adalah lembar observasi, lembar wawancara, dan dokumen. Pemeriksaan keabsahan dalam penelitian ini menggunakan teknik triangulasi sumber. Berdasarkan hasil penelitian dan pembahasan dapat diambil kesimpulan bahwa: (1) Alat yang digunakan dalam makan besaprah adalah: alas saprah, batel, pinggan saprah, piring laok, pinggan nase', cawan, baki ae', baki laok, sarbet dan berkaitan dengan konsep bangun datar, bangun ruang, pola bilangan, dan geometri. (2) Adapun aktivitas yang dilakukan dalam makan besaprah yaitu aktivitas persiapan sebelum makan besaprah yang dilakukan Melayu Sambas ada empat, yaitu merancap, bekaot, nyiapkan sajian saprahan, besurong.
\end{abstract}

Kata kunci: Etnomatematika; makan besaprah; etnografi.

\begin{abstract}
The purpose of this research is to describe the tools used and the activities carried out in the tradition of eating besaprah at the Malay wedding ceremony in Sambas District. The method used in this research is qualitative research in the form of ethnography. Data collection techniques used were observation, interviews, and documentation so that the data collection tools used were observation sheets, interview sheets, and documents. The validity check in this study uses the source triangulation technique. Based on the results of research and discussion, it can be concluded that: (1) The tools used in eating besaprah are alas saprah, batel, pinggan saprah, piring laok, pinggan nase', cawan, baki ae', baki laok, sarbet and are related to the concept geometry and number patterns. (2) As for the activities carried out in eating besaprah, there are four preparatory activities before eating besaprah by Sambas Melayu: merancap, bekaot, nyiapkan sajian saprahan, besurong.
\end{abstract}

Keywords: Ethnomatematics; eating besaprah; ethnography.

\section{PENDAHULUAN}

Pendidikan dan kebudayaan adalah dua unsur yang saling berkaitan dan bahkan bisa saling berpengaruh walaupun sebenarnya pendidikan merupakan bagian dari kebudayaan, tetapi perkembangan kebudayaan tentu juga dipengaruhi oleh pendidikan. Kebudayaan yang tidak disentuh oleh pendidikan maka akan statis dan tidak berkembang. Selain itu, pendidikan yang tidak mempertimbangkan budaya maka akan sulit diterima oleh masyarakat setempat. Oleh sebab itu, pendidikan khususnya dalam pembelajaran seyogyanya memasukkan unsur budaya atau adat istiadat yang sekiranya mudah diterima oleh masyarakat lebih khusus oleh peserta didik.

Perkembangan dan kemajuan teknologi informasi saat ini membuat kebudayaan atau tradisi yang ada di masyarakat semakin lama semakin 
hilang. Anak-anak lebih suka bermain gadget di rumah dari pada harus bermain engklek. Anak-anak yang sudah masuk SMP/MTs sudah tidak mau ke surau atau masjid untuk belajar membaca Al-Qur'an dan lebih memilih berada di depan TV atau laptop. Oleh sebab itu, kebudayaan atau tradisi seharusnya dilestarikan dan dikembangkan. Salah satunya dengan cara memasukkan unsur budaya dan tradisi dalam proses pembelajaran di kelas.

Hubungan antara pendidikan dan budaya, lingkungan sekitar atau alam semesta sudah lama disinggung dalam Al-Qur'an agar pendidikan dan budaya dapat dijadikan sarana dalam mengembangkan kepribadian manusia. Seperti dalam Al-Qur'an pada surat Yunus ayat 101.

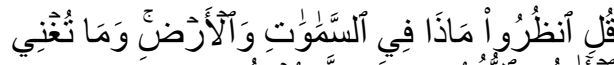

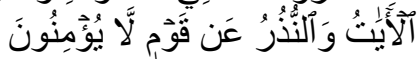

Artinya:

Katakanlah: "Perhatikanlah apa yang ada di langit dan di bumi. Tidaklah bermanfaat tanda kekuasaan Allah dan rasul-rasul yang memberi peringatan bagi orang-orang yang tidak beriman". (10: 101)

Dalam ayat tersebut, Al-Qur'an memerintahkan kepada manusia agar memperhatikan alam sekitar sehingga bisa mengambil dan memperoleh pelajaran dan pengetahuan dari alam sekitar tersebut. Alam sekitar tidak hanya berupa tata surya, galaksi maupun mineral yang ada di bumi, tetapi adat istiadat dan budaya termasuk bagian alam sekitar yang seharusnya dipelajari dan diambil manfaatnya untuk kepentingan masyarakat, pendidikan khususnya dalam proses pembelajaran. Selain itu, islam sangat memperhatikan budaya dan adat istiadat dalam memberikan hukum dalam aktivitas manusia.

Salah satu tradisi islam yang berkembang di masyarakat Melayu Sambas adalah Makan Besaprah pada upacara adat pernikahan, kegiatan tersebut sudah menjadi ikon dari masyarakat khususnya masyarakat melayu di daerah tersebut. Sebenarnya tidak ada referensi yang menyebutkan secara pasti sejak kapan tradisi makan besaprah ini dimulai, namun banyak pihak yang mengaitkan tradisi ini dengan ajaran Islam sebagai agama yang dianut masyarakat melayu Sambas.

Makan besaprah itu sendiri sebenarnya sudah ada pada zaman Rasulullah SAW dimana Rasulullah SAW memerintahkan kepada para sahabat untuk makan bersama sebagaimana istilah yang disebut makan besaprah. Seperti hadist-hadist di bawah ini:

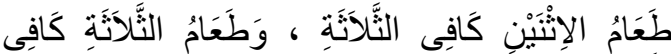

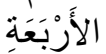

Artinya:

"Makanan porsi dua orang sebenarnya cukup untuk tiga, makanan tiga cukup untuk empat." (HR. Bukhari no. 5392 dan Muslim no. 2059, dari Abu Hurairah). Dalam lafazh Muslim disebutkan,

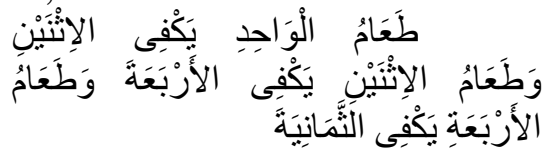

Artinya

"Makanan porsi satu orang sebenarnya cukup untuk dua, makanan dua sebenarnya cukup untuk empat, dan makanan empat sebenarnya cukup untuk delapan.

Makan besaprah termasuk ajaran islam yang diperintahkan oleh Allah SWT melalui Rasulullah SAW 
yang seharusnya dilestarikan. Dalam pelaksanaannya, setiap kelompok beranggotakan 6 orang yang disebut 1 saprahan.

Penelitian terkait etnomatematika ini sudah banyak dilakukan oleh para peneliti sebelumnya seperti yang dilakukan Khairadiningsih (2015) menyimpulkan bahwa hasil eksplorasi etnomatematika masyarakat suku Madura di Situbondo pada aktivitas membilang juga terlihat pada caranya menyebutkan bilangan $1,2,3$. Muzdalipah \& Yulianto (2015) menyimpulkan bahwa beragam aktivitas budaya masyarakat kampung Naga mengandung unsur-unsur matematika. Hasil penelitian Ngiza, Susanto, \& Lestari (2015) menunjukkan bahwa petani secara telah menggunakan aktivitas matematika dalam kegiatan bertani pada saat bercocok tanam padi maupun jeruk desa Sukoren. Hardiarti (2017) tentang etnomatematika: aplikasi bangun datar segiempat pada candi muaro jambi. Hartoyo (2012) tentang Etnomatematika Pada Budaya Masyarakat Dayak Perbatasan Indonesia-Malaysia Kabupaten Sanggau Kalbar. Akan tetapi dari berbagai hasil penelitian saat ini, belum ada etnomatematika yang mengkaji dari sudut pandang keislaman khususnya makan besaprah. Sudah banyak penelitian terkait makan besaprah, namun penelitian tersebut belum dikaitkan dengan etnomatematika.

Seperti hasil penelitian yang dilakukan Syahrin \& Nurida (2018) bahwa terdapat usaha-usaha dalam melestarikan budaya makan besaprah serta karakteristik masyarakat Melayu Sambas. Oleh sebab itu, penelitian ini dilakukan terkait konsep-konsep matematika yang terkandung dalam tradisi islam masyarakat Melayu Sambas yang ada di kecamatan Sambas serta ingin melestarikan kebudayaan yang ada di masyarakat terutama tradisi makan besaprah ini. Selain itu, penelitian ini juga berdasarkan hasil penelitian Khan, Zafar, \& Ansari (2011) bahwa banyak seni dalam islam yang mengandung unsur geometri yang artinya budaya-budaya islam banyak mengandung konsep matematika yang perlu dieksplorasi lagi.

Ada beberapa temuan yang sudah didapatkan seperti jumlah orang yang menikmati hidangan, jenis lauk dan jumlah sendok yang digunakan. Temuan ini diduga mengandung unsur maupun konsep matematika dan tentu masih banyak lagi tradisi, aktivitas, maupun peralatan yang digunakan dalam tradisi makan besaprah yang diduga mengandung unsur matematika. Oleh sebab itu, dilakukan penelitian lebih mendalam terkait temuan awal maupun aktivitas dan peralatan yang lain yang belum terungkap. Tujuan dalam penelitian adalah untuk mendiskripsikan alat-alat yang digunakan maupun aktivitas yang dilakukan dalam tradisi makan besaprah pada upacara pernikahan melayu di Kecamatan Sambas.

\section{METODE PENELITIAN}

Metode yang digunakan dalam penelitian ini adalah metode deskriptif. Adapun tujuan penelitian ini adalah untuk mendeskripsikan hasil eksplorasi etnomatematika islami pada makan besaprah yang berkaitan dengan matematika. Bentuk penelitian yang digunakan dalam penelitian ini adalah penelitian kualitatif dengan pendekatan etnografi.

Dalam penelitian ini yang menjadi tempat penelitian adalah kota yang memiliki karakteristik yang mendukung yaitu: Kota yang dikenal dengan kuatnya penjagaan Adat Istiadat 
Budaya Melayu yang identik dengan Islam turun temurun di masyarakat maka di Kabupaten Sambas sebagai lokasi penelitian yaitu Kecamatan Sambas khususnya di beberapa desa yaitu desa Durian, desa Tumuk, desa Dalam kaum. Lokasi ini dipilih karena desa tersebut terletak di Kecamatan Sambas di samping sebagai Kota Pusat Kabupaten, juga terdapat banyak peninggalan bersejarah seperti Istana Kerajaan Islam Sambas, Makam para Sulthan dan Ulama serta masih lestarinya tradisi makan besaprah pada setiap acara pesta pernikahan disamping berakulturasinya dengan pengaruh modern seperti presmanan yang bernuansa modern. Subjek penelitian ini adalah ustad dan tokoh adat di desa Durian, desa Dalam Kaum Kecamatan Sambas dan masyarakat Melayu Kecamatan Sambas.

Teknik pengumpulan data yang digunakan adalah observasi, wawancara, dan dokumentasi sehingga alat pengumpul data yang digunakan adalah lembar observasi, lembar wawancara, dan dokumen. Lembar observasi digunakan untuk mengamati alat yang digunakan dalam acara saprahan, lembar wawancara digunakan untuk mewancarai subjek penelitian, dan dokumen dalam penelitian ini adalah foto/dokumen mengenai peralatan maupun aktivitas dalam saprahan. Pemeriksaan keabsahan dalam penelitian ini menggunakan teknik triangulasi sumber. Sumber penelitian ini adalah tokoh adat, ustad, dan masyarakat.

Adapun teknik analisis data yang digunakan dalam penelitian ini adalah analisis data kualitatif. Analisis data kualitatif adalah bersifat induktif, yaitu suatu analisis berdasarkan data yang diperoleh baik itu dari hasil wawancara maupun hasil pengamatan yang

dilakukan secara terus menerus dan selanjutnya dikembangkan atau menjadi suatu deskripsian dan rangkuman agar memperoleh hasil akhir dari penelitian tersebut.

\section{HASIL PENELITIAN DAN PEMBAHASAN}

Alat-alat pada tradisi makan besaprah 1. Alas Saprah

Alas saprah (kain saprah) ini merupakan kain ukuran pendek $1 \times 1$ meter digunakan sebagai alas dan di atasnya diletakkan sajian makanan yang akan dinikmati oleh para tamu. Alas saprah dapat dilihat pada Gambar 1.

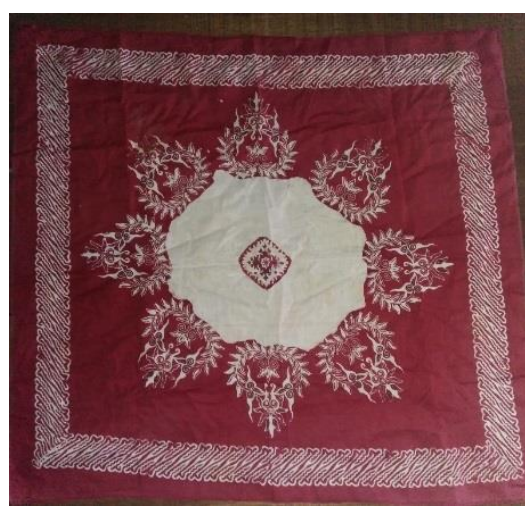

Gambar 1. Alas saprah

Unsur matematika: mengandung konsep matematika bangun datar, (2) memiliki empat sudut, dan (3) dibuat dari kain dengan ukuran $1 \times 1$ meter sehingga memiliki bentuk persegi.

\section{Batel}

Batel adalah wadah yang digunakan untuk mencuci tangan sebelum menyantap makanan. Orangorang terdahulu menamainya dengan sebutan batel dan gelas air, karena antara wadah air dan penampung air bekas cucian tangan terpisah. Tetapi saat sekarang biasanya sudah menjadi satu bagian, dan terkadang hanya menggunakan mangkuk kecil atau yang 
sering dikenal dengan sebutan kobokan. Gambar batel dapat dilihat pada Gambar 2.

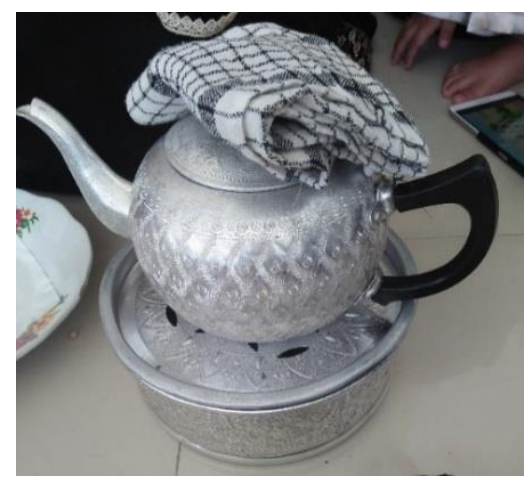

\section{Gambar 2. Batel}

Unsur matematika: memiliki konsep matematika bangun datar dan bangun ruang, bagian penutup batel tempat menampung air cucian tangan memiliki bentuk lingkaran, bagian penampung air cucian tangan memiliki bentuk menyerupai tabung dengan bagian atas tanpa alas melainkan hanya terdapat bagian penutup yang berbentuk lingkaran, yang bisa dilepas.

\section{Pinggan Saprah}

Pinggan saprah adalah pinggan berukuran besar digunakan sebagai tempat nasi yang akan disantap cukup keperluan enam orang dalam satu saprahan yang berjumlah enam orang. Pinggan saprah dapat dilihat pada Gambar 3.

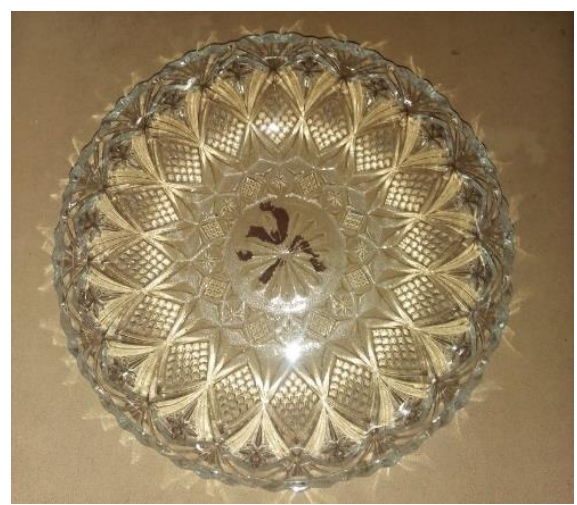

Gambar 3. Pinggan saprah
Unsur matematika: memiliki konsep matematika bangun datar dan pada bagian pinggan yang mengarah ke luar, permukaannya berbentuk lingkaran.

\section{Piring laok}

Piring laok adalah piring yang digunakan sebagai tempat lauk dengan menu/jenis lauk sebanyak lima atau enam piring (berdasarkan kemampuan masing-masing pelaksana pesta). Piring lauk dapat dilihat pada Gambar 4.

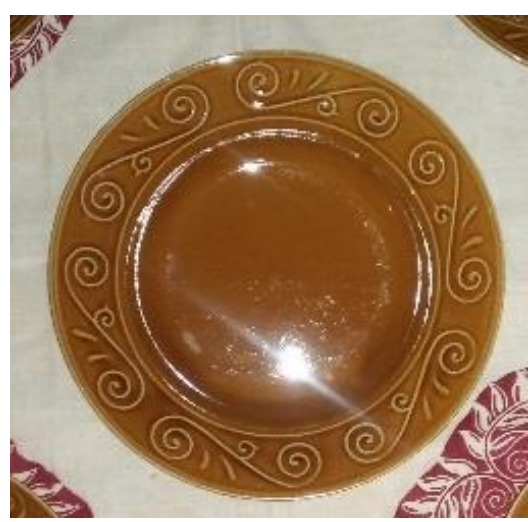

Gambar 4. Piring laok
Unsur matematika: memiliki konsep matematika bangun datar dan memiliki bentuk permukaan berbentuk lingkaran.

\section{Pinggan nase'}

Pinggan nase' adalah tempat menempatkan nasi sebanyak enam buah untuk enam orang (sesaprah). Pinggan nase' dapat dilihat pada Gambar 5. 


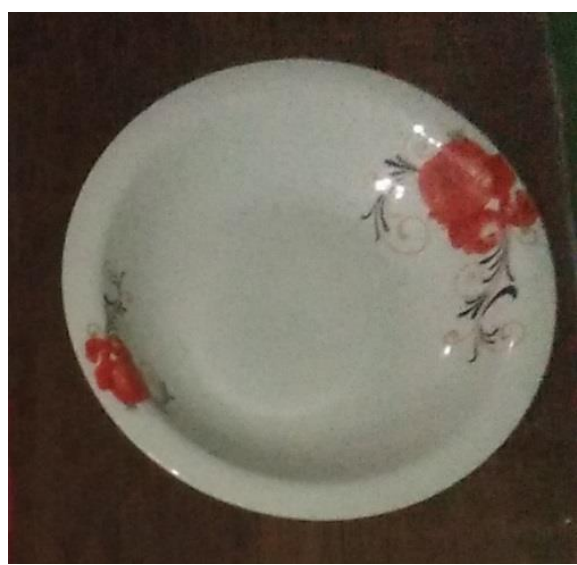

Gambar 5. Pinggan nase’

Unsur matematika: memiliki konsep matematika bangun datar dan permukaan berbentuk lingkaran.

\section{Cawan}

Cawan adalah gelas tempat air minum dengan alas yang diletakkan dibawah gelas. Didalam satu saprah maka memerlukan cawan sebanyak enam buah. Cawan yang diisi dengan air bergula. Cawan dapat dilihat pada Gambar 6.

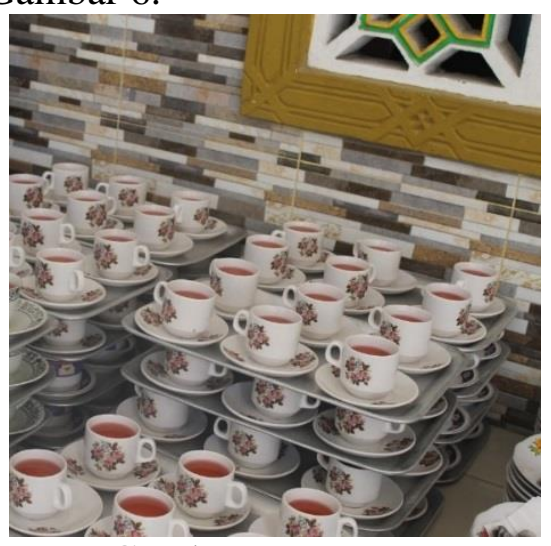

Gambar 6. Cawan

Unsur matematika: memiliki konsep matematika bangun datar dan bagian alas cawan bentuk permukaannya lingkaran.

\section{Baki laok}

Baki laok ini talam berukuran besar dan digunakan untuk menyajikan makanan, nama lain yaitu nampan. Baki ini berukuran besar sehingga bisa membawa sajian lauk dalam satu saprah. Tidak hanya untuk membawa sajian saprahan, namun baki ini terkadang digunakan sebagai alas dalam penyajian menu saprahan. Untuk yang berbentuk persegi panjang digunakan untuk menyajikan saprahan membujur dengan alas baki, sedangkan baki yang berbentuk bulat untuk menyajikan saprahan yang berbentuk bulat. Baki ini pada saat sekarang sudah memiliki banyak variasi dari mulai bentuk dan bahan, Gambar 7 adalah contoh baki yang digunakan orang jaman dahulu sehingga sudah menjadi barang antik. Baki laok dapat dilihat pada Gambar 7.
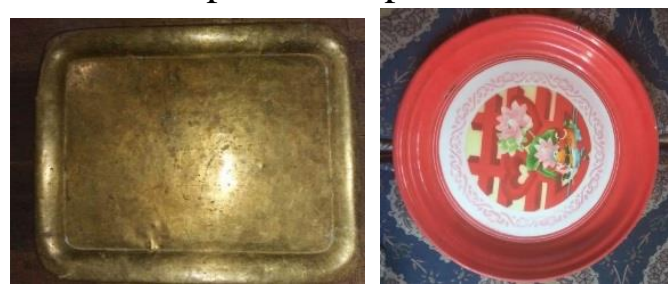

Gambar 7. Baki laok

Unsur matematika: mengandung konsep matematika bangun datar, $b$ erbentuk persegi panjang, bibir tebal melebar keluar dengan setiap sisi melengkung, dan pada bagian permukaan baki bulat berbentuk lingkaran.

\section{Baki ae'}

Baki ae' ini bentuknya memiliki kesamaan dengan baki laok, namun ukurannya lebih kecil. Sehingga dipergunakan untuk membawa minuman. Gambar baki ae' dalam berbagai bentuk dapat dilihat pada Gambar 8. 


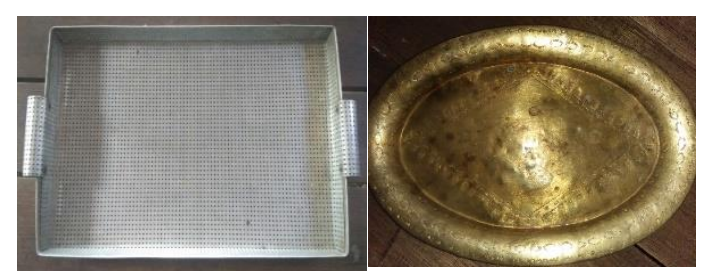

Gambar 8. Baki ae’

Unsur matematika: memiliki konsep matematika bangun datar, berbentuk persegi panjang dengan pinggiran baki bagian atas memiliki empat sudut dan bentuk lain yaitu berbentuk oval, dan lingkaran.

\section{Sarbet}

Sarbet adalah sebuah kain untuk lap tangan ketika selesai menyantap sajian. Sarbet dapat dilihat pada Gambar 9.

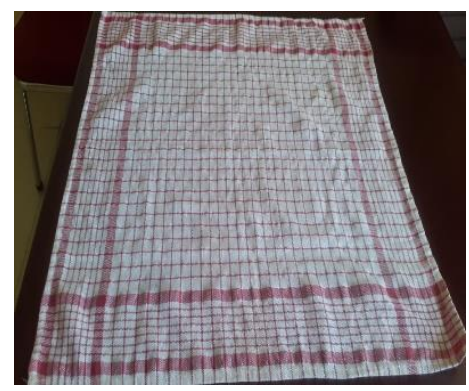

Gambar 9. Sarbet

Unsur matematika: memiliki konsep matematika bangun datar persegi dan memiliki empat sudut.

\section{Aktivitas pada tradisi makan besaprah \\ 1. Merancap \\ Merancap ini adalah mengatur} barang saprahan/pecah belah dengan menyamakan warna dan bentuknya baik itu pinggan ataupun piring lauk. Kemudian piring dan pinggan yang sudah dipilih disusun rapi, piring sesuai dengan jumlah dan jenis masakan yang akan disajikan. Dalam perhitungan merancap ini dihitung banyaknya piring lauk setiap saprah yang disajikan dan jumlah saprah yang akan disajikan nantinya. Merancap dapat dilihat pada Gambar 10.

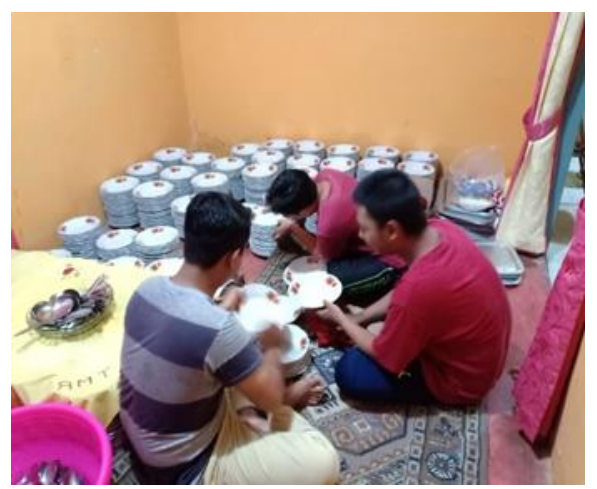

Gambar 10. Merancap

Unsur matematika: konsep matematika yang dimuat dalam aktivitas merancap yaitu operasi hitung bilangan bulat, operasi hitung penjumlahan pada saat estimasi banyak tamu undangan ketika menghitung banyak alat-alat makan besaprah yang digunakan dengan menyesuaikan warna dan bentuk bunga pada pinggan ataupun piring lauk dan kemudian piring dan pinggan yang sudah disusun rapi disesuaikan dengan jumlah dan jenis masakan yang akan disajikan.

\section{Bekaot}

Bekaot adalah memasukkan nasi dalam pinggan saprah, dan mengisi lauk kedalam piring-piring yang disiapkan dengan jenis masakan yang sudah selesai dimasak. Piring-piring disusun berurutan dan disesuaikan dengan jenis masakan yang disiapkan sehingga nantinya akan mudah untuk mengambilnya. Adapun tugas seksi bekaot ialah menyiapkan air minum, dan setelah gelas diisi air maka selanjutnya meletakkan ke dalam baki kecil. Bekaot dapat dilihat pada Gambar 11. 


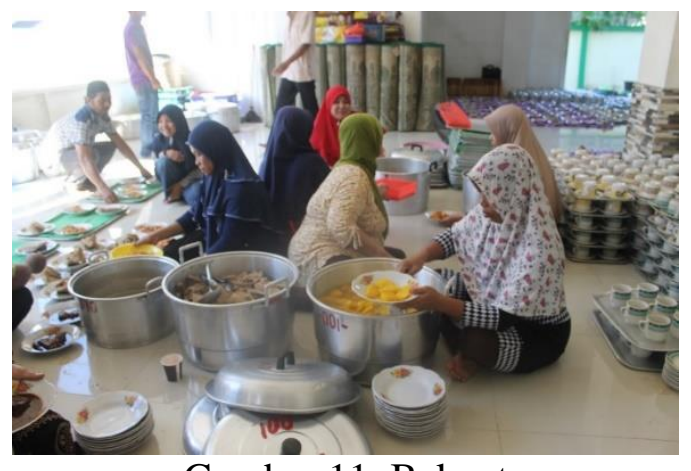

Gambar 11. Bekaot

Unsur matematika: konsep matematika yang ada dalam aktivitas bekaot ialah operasi hitung penjumlahan ketika menghitung dan memperkirakan banyak nasi, lauk yang akan disajikan harus sama rata untuk semua tamu dalam saprahan dan mengandung konsep pengukuran pada saat jenis masakan disusun berurutan sesuai dengan jenis masakan disiapkan. Disusun sedikit berjarak, agar memudahkan dalam pengambilan. Ada juga bagian menyiapkan air minum yang diisi air ke dalam gelas yang memiliki konsep matematika volume.

\section{Ngator Sajian}

Setelah bekaot (menyiapkan sajian saprahan) dilanjutkan dengan mengatur sajian saprahan agar persiapan selanjutnya lebih teratur. Yang pertama dilakukan ialah melipat kain saprah dengan cara dilipat khusus hal ini dimaksudkan agar ketika dihadapan undangan, penyurrong (pramusaji) tidak sulit untuk membukanya. Pinggan yang digunakan untuk lauk maupun nasi haruslah disamakan bentuk dan bunganya serta disesuaikan jumlahnya, dan setelah diisi diletakkan ke dalam baki besar, cawan atau gelas air minum diletakkan dalam baki kecil dengan setiap baki di isi enam cawan. Ngator sajian dapat dilihat pada Gambar 12.

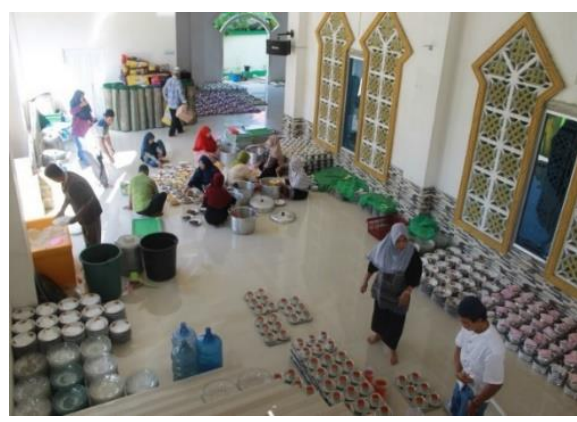

Gambar 12. Ngator sajian

Unsur matematika: a) Konsep matematika yang dimuat dalam aktivitas ngator sajian adalah ketika menyusun sajian ke dalam suatu tempat (emperemper) dimana akan disusun berdasarkan jenisnya sambil dihitung agar jumlahnya pas. b) Pada bagian mengatur air minum juga menyiapkan air cuci tangan yaitu batel sehingga untuk satu saprah dihitung jumlah air minum sebanyak enam cawan air, dan disiapkan juga satu buah batel untuk tiap satu saprah. Begitu selanjutnya berlaku kelipatan dalam menentukan jumlah banyak nya air yang disiapkan, apabila untuk 100 saprah sama banyak gelas yang dipakai ialah sebanyak 600 cawan air minum dengan 100 batel yang diperlukan. c) Kain saprah juga harus dilipat khusus pada aktivitas ini agar dihadapan undangan tidak mengalami kesulitan dalam membukanya, sehingga dalam aktivitas ini terdapat konsep bangun datar. Dimana dalam pelipatan tersebut kain yang berada pada setiap sudut dilipat ke dalam sehingga membentuk segitiga. Dan lipatan pada sudut yang atas dilipat paling terakhir, sehingga nantinya kain tersebut akan membentuk bangun datar persegi yang lebih kecil dari sebelum dilakukan pelipatan.

Pada aktivitas ngator sajian (mengatur sajian saprahan) terdapat aktivitas dimana alas saprah dilipat dengan aturan khusus. Dari bentangan kain tersebut setiap ujung yang lancip 
dilipat ke dalam sehingga masingmasing membentuk segitiga, dengan bagian dalam akan terbentuk bangun persegi. Gambar 13 adalah contoh melipat alas saprah.

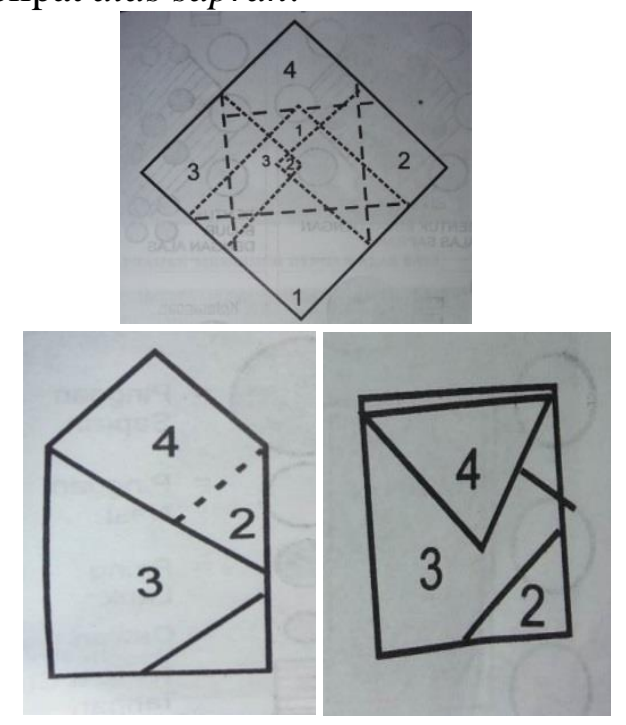

Gambar 13. Melipat alas saprah

\section{Besurrong}

Besurrong adalah mengangkat sajian kehadapan tamu undangan yang sedang duduk bersila diatas hamparan tikar permadani yang khusus. Orang yang membawa sajian disebut dengan penyurrung, orang tersebut memakai pakaian melayu yang seragam. Jumlah penyurrung ada lima orang yang mempunyai tugas masing-masing. Sajian saprahan dibawa secara sambung menyambung (estafet) antara penyurrung ke penyurrung lain, sebagai contoh penyurrung utama meletakkan sajian-sajian yang di terimanya dari penyurrung ke 2 dan seterusnya sampai selesai. Begitu seterusnya sampai seluruh undangan mendapatkan sajian saprahan. Besurrong dapat dilihat pada Gambar 14.

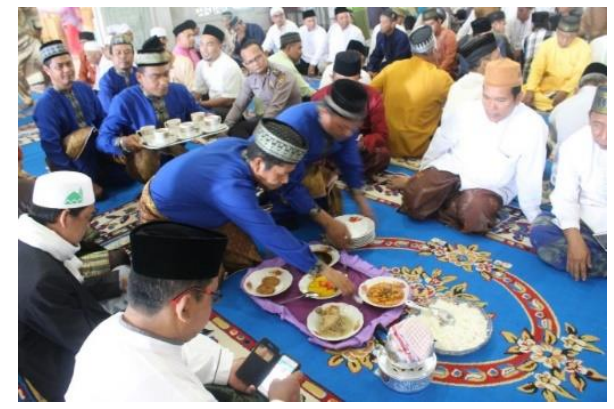

Gambar 14. Besurrong

Unsur Matematika: a) Pada aktivitas bessurong ini mempunyai aturan tertentu, contohnya jumlah orang yang bertugas dalam bessurong berjumlah lima orang pramusaji (tukang angkat sajian). Orang yang bertugas sebagai pramusaji disebut penyurrong, mereka memiliki tugasnya masingmasing yaitu sajian saprahan disampaikan secara sambung menyambung (estapet) dari penyurrong pertama sampai penyurrong kedua begitu seterusnya sampai selesai dan kembali dengan serempak pada posisi awal. b) Aktivitas juga muncul ketika menyusun sajian dihadapan para undangan, dalam penyajian makanan memiliki aturan tertentu. Ada beberapa pola yang digunakan dalam saprahan, contohnya sajian dibuat berbentuk bulat menyerupai lingkaran, membujur atau menyerupai persegi panjang.

Kebudayaan adalah hal yang tidak bisa dilepaskan dari kebudayaan. Budaya bisa menjadi jembatan perserta didik dalam memahami konsep matematika dengan cara memanfaatkan budaya/tradisi yang mengandung unsur/konsep matematika ke dalam proses pembelajaran. Selain itu, nilainilai budaya dapat diupayakan dalam pembangunan karakter peserta didik (Yunus, 2013). Berdasarkan hasil penelitian ini, terdapat alat-alat tradisi islam besaprah dalam upacara pernikahan yang bisa digunakan sebagai 
media dan alat peraga dalam pembelajaran di sekolah maupun madrasah dan terdapat aktivitas tradisi islam yang juga mengandung unsur matematika yang bisa dimanfaatkan dalam pembelajaran matematika. Alatalat tersebut adalah alas saprah, redang laok, redang ae', batel, cawan, pinggan saprah, pinggan nase', dan piring laok, sarbet adapun materi matematika yang dapat menggunakan alat-alat makan besaprah tersebut adalah bangun datar, bangun ruang, dan geometri.

Alat-alat tradisi makan besaprah tersebut digunakan dalam melakukan aktivitas makan besaprah. Dalam aktivitas makan besaprah juga terdapat aktivitas matematika yaitu menghitung dan mengukur. Aktivitas membilang berkaitan dengan pertanyaan "berapa banyak". Cara membilang ini sering digunakan dengan jari. Bahasa yang digunakan dalam bahasa Melayu Sambas: satu, dua', tige, ampat, lima', anam, tujoh, delapan, sembilan, sepuloh. Bilangan-bilangan tersebut menunjukkan angka satu sampai dengan sepuluh. Adapun bilangan belasan: seballas yang menunjukkan angka sebelas, dua' ballas menunjukkan angka dua belas begitu seterusnya. Bilangan tersebut digunakan saat menghitung jumlah alat yang diperlukan saat mempersiapkan pecah belah makan besaprah dan jumlah pekerja. Aktivitas membilang juga muncul pada saat menyatakan jumlah dalam satu saprah yaitu berjumlah enam orang dimana penyebutannya menjadi sesaprah. Adapun aktivitas menghitung juga muncul saat seksi merancap, meminjam barang pecah belah untuk makan besaprah yang diketuai oleh orang yang sudah berkomunikasi kepada tuan rumah pelaksana acara, dan yang sudah mengetahui berapa perkiraan jumlah pecah belah yang akan dipinjam apabila undangan yang akan hadir berjumlah sekian banyak orang. Pada saprahan terdapat beberapa tingkatan kelompok maka dari itu perkiraan jumlah pecah belah wajib diperhitungkan dengan benar, adapun kelompok saprahan yang pertama ialah saprahan sangat sederhana yang dapat ditemukan ketika dalam kegiatan makan bersama di rumah tangga baik itu untuk menjamu tamu yang berkunjung di rumah ataupun hanya sekedar makan bersama keluarga seisi rumah. Selanjutnya saprahan sederhana, saprahan ini dilakukan apabila ada pesta kecil seperti selamatan, tepung tawar dan sebagainya yang perlu menyiapkan saprahan kurang dari 20 saprah. Yang termasuk kedalam saprahan di acara pernikahan Melayu Sambas ini ialah saprahan acara pesta dimana tamu yang diundang sebanyak 600 sampai 1000 orang lebih, mungkin bisa lebih dari itu lagi.

Hasil penelitian ini sesuai dengan hasil penelitian Setiyawan, Kadir, \& Anggo (2019) bahwa terdapat beberapa konsep matematika dalam pernikahan (kawia'a) masyarakat Binongko. Penelitian Dominikus, dkk (2016) yang mengatakan bahwa terdapat alat dan aktivitas didalam pernikahan adat yang mengandung unsur matematika. Ada juga penelitian lainnya yaitu yang dilakukan oleh Mun'in (2017) hasil penelitian menunjukkan bahwa pada alat dan aktivitas makan besaprah terdapat konsep matematika yang dapat digunakan dalam pembelajaran matematika di Sekolah terutama matematika. Selain makan besaprah yang biasa dilakukan dalam tradisi pernikahan, tradisi Islam yang juga mengandung unsur matematika adalah rebana (Putri, 2017).

Hasil temuan ini bisa menjadi rujukan untuk penelitian-penelitian berikutnya bahwa tradisi islam yang 
lain bisa dieksplorasi sehingga bisa dimanfaatkan dalam proses pembelajaran. Tradisi islam tidak hanya mengandung unsur-unsur matematika saja tetapi masih banyak lagi yang bisa dikaji. Tradisi islam seharusnya dapat dijadikan salah satu jembatan atau sarana dalam menyampaikan materi pelajaran khususnya matematika. Selain itu, tradisi atau budaya sangat dekat dengan siswa sehingga pembelajaran yang dihubungkan dengan budaya atau kegiatan yang sering dialami oleh siswa akan membantu dan mempermudah siswa dalam memahami konsep yang akan diajarkan oleh guru. Dengan mengekslorasi dan memanfaatkan budaya islami berarti kita juga ikut terlibat dalam pelestarian budaya islam.

\section{KESIMPULAN DAN SARAN}

Berdasarkan hasil penelitian dan pembahasan dapat diambil kesimpulan mengenai etnomatematika islami yang terdapat pada tradisi makan besaprah suku melayu di Kabupaten Sambas yaitu: (1) Alat yang digunakan dalam makan besaprah terdapat sembilan alat yang memiliki kegunaannya masingmasing. Alat-alat makan besaprah yang dapat dijadikan alat penunjang pembelajaran di Sekolah yaitu alas saprah, batel, pinggan saprah, piring laok, pinggan nase', cawan, baki ae', baki laok, sarbet dan berkaitan dengan konsep bangun datar, bangun ruang, pola bilangan, dan geometri. (2) Adapun aktivitas yang dilakukan dalam makan besaprah yaitu aktivitas persiapan sebelum makan besaprah yang dilakukan Melayu Sambas ada empat, yaitu merancap, bekaot, nyiapkan sajian saprahan, besurong.

Penelitian ini diharapkan sebagai langkah awal dalam penelitian etkomatematika islami yang mengkaji makan besaprah. Oleh sebab itu, diharapkan para peneliti dapat mengeksplorasi penelitian-penelitian berikutnya terkait etonomatematika islami yang ada pada budaya atau tradisi islam seperti akikah, empat bulanan dan tujuh bulanan, kurban, khitananm, dan lain-lain. Selain itu, hasil penelitian ini diharapkan dapat memberikan wawasan kepada pendidik agar mengoptimalkan etonomatematika (budaya setempat) dalam pembelajaran matematika.

\section{UCAPAN TERIMA KASIH}

Terima kasih kami sampaikan kepada IKIP PGRI Pontianak atas dana Hibah Penelitian Tahun Anggaran 2019 yang telah diberikan.

\section{DAFTAR PUSTAKA}

Dominikus, W. S., Nusantara, T., Subanji, \& Muksar, M. (2016). Link Betweeen, Ethomatematics in Marriage Tradition in Adonara Island and School Mathematics. IOSR Journal of Research \& Method in Education (IOSRJRME), 6(3), 56-62.

Hardiarti, S. (2017). Etnomatematika: Aplikasi Bangun Datar Segiempat pada Candi Muaro Jambi. Aksioma, 8(2), 99-110.

Hartoyo, A. (2012). Eksplorasi Etnomatematika Pada Budaya Masyarakat Dayak Perbatasan Indonesia-Malaysia Kabupaten Sanggau Kalbar. Jurnal Penelitian Pendidikan, 13(1), 1423.

Khan, K., Zafar, A., \& Ansari, M. R. K. (2011). Islamic art, mathematics and heritage of Sindh. The Sindh University Journal of EducationSUJE, 40(1),58-73. 
DOI: https://doi.org/10.24127/ajpm.v8i3.2385

Khairadiningsih, R. N. (2015). Eksplorasi Etnomatematika Masyarakat Suku Madura di Situbondo. Artikel Ilmiah Mahasiswa, 2(1), 1-4.

Mun'in, F. (2017). Eksistensi Tradisi Pembacaan Assalai/Asy'rakal Dan Makan Besaprah Pada Pesta Pernikahan Masyarakat Melayu Kabupaten Sambas Perspektif Ekonomi Islam. Khatulistiwa, 7(2). 1-18. Muzdalipah, I. \& Yulianto, E. (2015). Pengembangan Desain Pembelajaran Matematika untuk Siswa SD Berbasis Aktivitas Budaya dan Permainan Tradisional Masyarakat Kampung Naga. Jurnal Siliwangi Seri Pendidikan, 1(1), 63-74.

Ngiza, L. N., Susanto, \& Lestari, N. D. S. (2015). Identifikasi Etnomatematika Petani pada Masyarakat Jawa di Desa Sukoreno. Artikel Ilmiah Mahasiswa, 1(1), 1-6
Putri, L. I. (2017). Eksplorasi etnomatematika kesenian rebana sebagai sumber belajar matematika pada jenjang MI. Jurnal Ilmiah Pendidikan Dasar, 4(1), 21-31.

Setiyawan, W. O. N., Kadir, K., \& Anggo, M. (2019). Eksplorasi Etnomatematika Pernikahan (Kawia'a) Masyarakat Binongko. Jurnal Pembelajaran Berpikir Matematika (Journal of Mathematics Thinking Learning), 4(1), 1-11.

Syahrin, A. A. \& Nurida, T. D. (2018). Eksistensi Bahasa Melayu Sambas dalam Budaya Makan Besaprah Masyarakat Melayu Sambas. Seminar Internasional Riksa Bahasa (pp. 367-376).

Yunus, R. (2013). Transformasi nilainilai budaya lokal sebagai upaya pembangunan karakter bangsa. Jurnal Penelitian Pendidikan, 13(1), 67-79. 